\title{
Making a splash
}

\section{A web focus spotlights some of the potential impacts of climate change on the world's water resources.}

Climate change is expected to affect water resources, with implications for both natural ecosystems and human food security. Nature Climate Change and Nature Geoscience are jointly presenting 'Water in a warming world', a collection of articles highlighting many of the key issues in this important area of climate change research; the focus will be available from Monday 3 December at http://www.nature.com/nclimate/focus/ water-warm-world/index.html. Here we highlight some of the new content to be included from this journal.

Complacency over water availability is misguided. We need hardly emphasize the primary importance of water for life, including our own, but in addition to drinking water and other domestic requirements vast amounts of freshwater are needed for agriculture and industry, as well as in power generation, so disruptions to supply can be economically crippling. At an international level, disputes over water resources are likely to intensify with human population growth - and climate change could exacerbate such tensions.

Among the most damaging natural disasters are droughts. Aiguo Dai of the United States' National Center for
Atmospheric Research in Boulder, Colorado, shows that observed changes in global aridity since 1923 are broadly consistent with Earth-system model simulations (http://go.nature.com/dQEws7). These models suggest that widespread droughts will increase in the coming decades over many land areas.

North America's Rocky Mountains are a source-water region for over 60 million people. They are also famous for their lodgepole pine forests. However, climate change has made these forests more prone to pest outbreak, and around four million acres of forest have been affected by an ongoing bark-beetle epidemic. Kristen Mikkelson of the Colorado School of Mines and her collaborators report that large-scale tree die-off can detrimentally affect water quality (http://go.nature.com/oQbE3w), potentially affecting water availability to millions.

Groundwater represents the largest source of distributed freshwater on Earth. International scientists led by Richard Taylor of University College London, UK, review recent research assessing climate impacts on groundwater as well as groundwater-climate feedbacks (http://go.nature.com/uKsxFF). Based on their analysis, they identify the need for systematic groundwater observations, and emphasize both the importance of managing groundwater sustainably and its strategic significance for climate adaptation.

Meanwhile, a team led by Quentin Grafton of The Australian National University examines the health of four major world rivers - the Colorado River in the United States, the Murray River in Australia, the Orange River in South Africa and the Yellow River in China (http://go.nature. com/qHyryL). All have suffered as a result of water use, climate variability and change. The researchers find that increased water extraction has severely compromised environmental flows and ecological function for all four rivers, and consider changes in management thinking aimed at achieving a better balance between water consumption and river health.

Finally, in an interview (http://go.nature. com/uGOqYC) Pavel Kabat, Director of the Austria-based International Institute of Applied System Analysis, explains the importance of the system analysis approach for identifying potential synergies among different water users, as is necessary for improved water management in the context of climate change adaptation.

\section{Justice sought at Doha}

\section{Nations will eventually reach a robust and long-lasting compromise on climate, but any agreement reached must be fair on the world's poorest people.}

The latest round of international climate negotiations under the United Nations Framework Convention on Climate Change is taking place at Doha, Qatar (26 November-7 December 2012). A major task for the 18th session of the Conference of the Parties (COP18) is to secure climate change commitments and to move towards credible post-2020 agreements on nations' carbon emissions reductions, other mitigation measures, and international economic support for adaptation measures, particularly in relation to the developing world.

Previous climate negotiations have been dogged by seemingly endless disputes and bickering. On page 834, Heike Schroeder and colleagues argue that progress to international cooperation on climate policy has also been hampered by highly inequitable United Nations structures that effectively handicap poorer nations. They note that
COP meetings have become increasingly dominated by wealthy nations able to afford to send large numbers of delegates with high levels of expertise, to the detriment - at least in terms of representation - of more cashstrapped developing nations.

They also argue that the very structure of meetings increases poor nations' vulnerability, because extremely lengthy and gruelling sessions end up exhausting smaller delegations disproportionately. Furthermore, they say, consensus-based decision-making (versus majority voting) has stifled progress and contributed to negotiation deadlocks, which ultimately cause most harm to the world's poor. They conclude that both the institutions and their structures require root-and-branch reform if justice in climate negotiations is to be achieved.

Not least due to their historical emissions, it can be argued that rich developed nations have particular responsibilities in climate negotiations and must be seen to lead by example. Jouni Paavola and colleagues (page 837) focus on the need for the European Union to foster and build on the 'coalition of ambition' that it so successfully developed along with the Alliance of Small Island States and some of the world's least developed counties a year ago in Durban, South Africa. They argue that the EU also needs to strengthen links with other key players such as Brazil and South Africa that supported its proposed roadmap to a post2020 deal. However, they note that to remain credible, the EU will need not only to "accommodate the interests of its potential allies on issues such as mitigation ambition, adaptation finance and deforestation," but also practice what it preaches, for example by committing to more ambitious targets for emissions reduction. 